\title{
SISTEM PAKAR DIAGNOSA JENIS GANGGUAN JIWA SKIZOFRENIA MENGGUNAKAN KOMBINASI METODE FORWARD CHAINING DAN CERTAINTY FACTOR
}

\author{
Windarsyah ${ }^{1)}$, Husnul Khatimi ${ }^{2)}$, dan Ryan Maulana ${ }^{3)}$ \\ 1,2,3) Program Studi Teknologi Informasi, Fakultas Teknik, Universitas Lambung Mangkurat \\ Jl. Brigjen H. Hasan Basri, Pangeran, Kec. Banjarmasin Utara, Kota Banjarmasin, Kalimantan Selatan 70123 \\ e-mail:', windarsyah@ulm.ac.id ${ }^{2}$, hkhatimi@ulm.ac.id ${ }^{1}$, iyaryan22@gmail.com ${ }^{3)}$
}

\begin{abstract}
ABSTRAK
Skizofrenia adalah gangguan kondisi medis atau disebut dengan gangguan kejiwaan yang mana mempengaruhi kemampuan otak pada manusia, mempengaruhi fungsi normal kognetif, emosional serta tingkah laku. Gangguan jiwa Skizorfenia terbagi menjadi lima jenis yaitu Skizofrenia Paranoid, Skizofrenia Simplek, Skizofrenia Katatonik, Skizofrenia Hebrefenik, dan Skizofrenia Residual. Salah satu cara untuk menentukan diagnosa jenis skizofrenia terhadap pasien adalah dengan cara konseling. Penelitian ini memiliki tujuan untuk membantu keputusan seorang ahli kejiwaan dalam menentukan diagnosa jenis skizofrenia terhadap pasien dengan menggunakan kombinasi metode forward chaining dan certainty factor. Forward chaining berfungsi sebagai mesin inferensi aturan di dalam sistem sedangkan certainty factor sebagai pemberi nilai kepercayaan pada sebuah aturan. Dalam membangun sistem ini dilakukan pengumpulan basis pengetahuan, resprentasi nilai certainty factor oleh pakar dan implementasi sistem berbasis website. Presentase dari hasil ujicoba sistem terhadap pakar adalah $93 \%$ sesuai.
\end{abstract}

Kata Kunci: Skizofrenia, forward chaining, certainty factor.

\section{ABSTRACT}

These instructions give you guidelines for preparing JTIULM (Jurnal Teknologi Informasi Universitas Lambung Mangkurat) papers. Use this document as a template if you are using Microsoft Word 6.0 or later. The electronic file of your paper will be formatted further by JTIULM editorial board. Paper titles should be written in uppercase. Avoid writing long formulas with subscripts in the title; short formulas that identify the elements are fine (e.g., "Nd-Fe-B"). Do not write "(Invited)" in the title. Full names of authors are preferred in the author field, but are not required. If you have to shorten the author name, leave first name and last name unshorten. Put a space between authors' initials. Do not cite references in the abstract. The length of abstract must between 150 - 250 words.

Keywords: Enter keywords or phrases in alphabetical order, separated by commas. The number of keywords must between 35 words.

\section{Pendahuluan}

$\mathrm{G}$ angguan jiwa terbagi menjadi gangguan jiwa berat dan ringan, salah satu jenis gangguan jiwa berat ialah gangguan jiwa skiozfrenia. Di Indonesia badan yang melakukan riset pada kejiwaan dilakukan oleh Riset Kesehatan Dasar (Riskesdas) yang mana dilakukan setiap 5-6 tahun sekali. Dari data Riskesdas tahun 2013 pervelansi gangguan jiwa berat skizofrenia terhitung antara empat ratus ribu orang atau sebanyak satu koma tujuh per seribu penduduk. Prevalensi gangguan jiwa berat di Kalimantan paling tinggi berada di Kalimantan Selatan yaitu 1,4 per mil [1]. Pada penelitian yang dilakukan oleh Norsyehan menyebutkan bahwa Rumah Sakit Jiwa Sambang Lihum yang terletak di Kalimantan Selatan, jumlah pasien rawat inap penderita Skizofrenia tercatat pada tahun 2011 sebanyak 1033 kasus, pada tahun 2012 tercatat 1498 kasus dan tahun 2013 tercatat 1813 kasus [2]. Hal ini menunjukan bahwa kasus Skizofrenia selalu meningkat setiap tahunnya.

Skizofrenia adalah gangguan kondisi medis atau disebut dengan gangguan kejiwaan yang mana mempengaruhi kemampuan otak pada manusia, mempengaruhi fungsi normal kognetif, emosional serta tingkah laku. Gangguan jiwa Skizorfenia terbagi menjadi lima jenis yaitu Skizofrenia Paranoid, Skizofrenia Simplek, Skizofrenia Katatonik, Skizofrenia Hebrefenik, dan Skizofrenia Residual [3]. Pada masa sekarang ini pengetahuan seorang ahli dapat dituangkan ke dalam sistem komputer atau bisa disebut dengan sistem pakar.

Sistem pakar merupakan sistem yang mengimplementasikan pengetahuan seorang ahli atau disebut pakar ke dalam sebuah sistem komputer yang mana bertujuan untuk mengambil sebuah keputusan layaknya seorang pakar. Implementasi sistem pakar biasanya diterapkan pada dunia kesehatan untuk membantu pasien dalam mengetahui diagnosa awal penyakit yang diderita dan sebagai alat bantu bagi dokter dalam mengambil sebuah keputusan. 
Ada banyak metode sistem pakar yang telah digunakan, untuk penentuan diagnosa penyakit, biasanya penggunaan metode forward chaining $(f c)$ yang paling banyak ditemui. Seperti penelitian yang dilakukan oleh Erianto Ongko yang berjudul perancangan sistem pakar diagnosa penyakit pada mata menggunakan metode $f c$, terbukti penggunaan metode forward chaining cukup membantu dengan tingkat keakuratan mencapai $91 \%$. Namun pada metode ini masih memiliki beberapa kelemahan, yaitu tidak diketahuinya tingkat kepercayaan pada hasil diganosa yang dihasilkan serta tidak memberikan kemungkinan hasil penyakit lainnya. Dengan kekurangan tersebut, metode yang cocok untuk melengkapi proses diagnosa jenis gangguan jiwa skizorfenia ialah metode certainty factor(cf) [4]. Fersalina melakukan penelitian diagnosis penyakit kejiwaan menggunakan metode certainty factor dengan tingkat keakuratan diangka 80\% [5]. Berbeda dengan forward chaining, kelebihan dari certainty factor yaitu hasil tingkat kepercayaan pada hasil diagnosa dapat diketahui dalam persentase dan kemungkinan penyakit lain dapat diketahui.

Berdasarkan penelitian sebelumnya, metode forward chaining dan metode certainty factor memiliki tingkat akurasi yang baik dalam pembuatan sistem pakar. Oleh karena itu, penelitian ini menggunakan kombinasi metode forward chaining dan metode certainty factor untuk menghasilkan sistem pakar diagnosa penyakit jenis gangguan jiwa skizofrenia sehingga dapat membantu ahli kejiwaan dalam mengambil keputusan diagnosa terhadap pasien secara cepat dan akurat.

\section{STUDI LITERATUR}

Pada bab ini akan memaparkan mengenai teori apa saja yang digunakan untuk menunjang pemecahan masalah.

\section{A. Skizofernia}

Skizofrenia adalah gangguan kondisi medis atau disebut dengan gangguan kejiwaan yang mana mempengaruhi kemampuan otak pada manusia, mempengaruhi fungsi normal kognetif, emosional serta tingkah laku. Gangguan jiwa Skizorfenia terbagi menjadi lima jenis yaitu Skizofrenia Paranoid, Skizofrenia Simplek, Skizofrenia Katatonik, Skizofrenia Hebrefenik, dan Skizofrenia Residual. Salah satu cara untuk menentukan diagnosa jenis skizofrenia terhadap pasien adalah dengan cara konseling [6].

\section{B. Sistem Pakar}

Sistem pakar adalah sebuah sistem yang mengimplementasikan pengetahuan atau kemampuan seorang manusia atau pakar ke dalam sistem, yang bertujuan menyelesaikan permasalahan dengan menirukan pengetahuan dari pakar. Dengan sistem pakar ini orang awam akan terbantu dalam menyelesaikan masalah yang bukan keahliannya. Untuk para ahli sistem pakar ini dapat membantu aktivitas mereka sebagai asisten yang berpengalaman dalam mengambil keputusan [7].

\section{Forward Chaining}

Metode Forward Chaining adalah metode pencarian atau teknik pelacakan ke depan yang dimulai dengan informasi yang ada forward chaining adalah salah satu metode dari sistem pakar yang mencari atau menelusuri solusi melalui masalah. Dengan kata lain metode ini melakukan pertimbangan dari fakta-fakta yang kemudian berujung pada sebuah kesimpulan yang berdasarkan pada fakta-fakta. Metode ini merupakan kebalikan dari metode backward chaining yang melakukan pencarian yang berawal dari hipotesis menuju ke fakta-fakta untuk mendukung hipotesis tersebut [8].

Pada metode forward chaining, penjelasan tidak terlalu terlalu terfasilitasi karena subgoals tidak diketahui secara eksplisit sebelum kesimpulannya ditemukan. Forward chaining disebut juga bottom-up reasoning atau pertimbangan dari bawah ke atas, karena metode ini mempertimbangkan dari bukti-bukti pada level bawah, faktafakta, menuju ke kesimpulan pada level atas yang berdasarkan pada fakta-fakta.

\section{Certainty Factor}

Metode yang digunakan pada penelitian kali ini ialah metode factor kepastian (certainty factor), metode ini merupakan suatu metode untuk membuktikan ketidakpastian pemikiran seorang pakar, dimana untuk mengakomodasi hal tersebut seseorang biasanya menggunakan certainty factor untuk menggambarkan tingkat keyakinan pakar terhadap masalah yang sedang dihadapi [9]. Terdapat dua faktor kepastian dalam certainty factor, yang pertama faktor kepastian yang diberikan oleh pakar yang mana nilai diberikan oleh pakar bernilai kepercayaan pakar terhadap antecedent dan konsekuen. Faktor yang kedua nilai kepercayaan dari pengguna yang mana nilai diisikan kepercayaan pengguna terhadap keberadaan elemen dalam antecedent. 
Khatimi, Windarsyah, dan Maulana — Sistem Pakar Diagnosa Jenis Gangguan Jiwa Skizofrenia Menggunakan Kombinasi

Nilai certainty factor didapat dari interpretasi "term" dari pakar yang diubah menjadi nilai certainty factor tertentu sesuai gambar 1. Aturan kombinasi certainty factor untuk mendapatkan hasil kesimpulan adalah sebagai berikut:

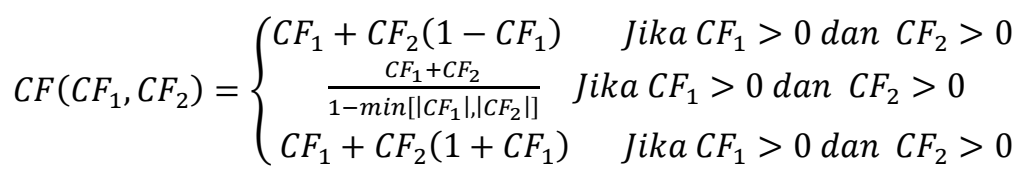

\section{ANALISIS PERMASALAHAN}

\section{A. Prosedur Penelitian}

Prosedur penelitan yang dilakukan pada penelitian ini dimulai dari beberapa tahapan yang mana untuk memudahkan proses pelaksaan penelitian dan juga sebagai pedoman dalam pelaksanaan penelitian agar tercapainya tujuan, tahapan prosedur penelitian yang akan dilakukan dapat dilihat pada Gambar 2.
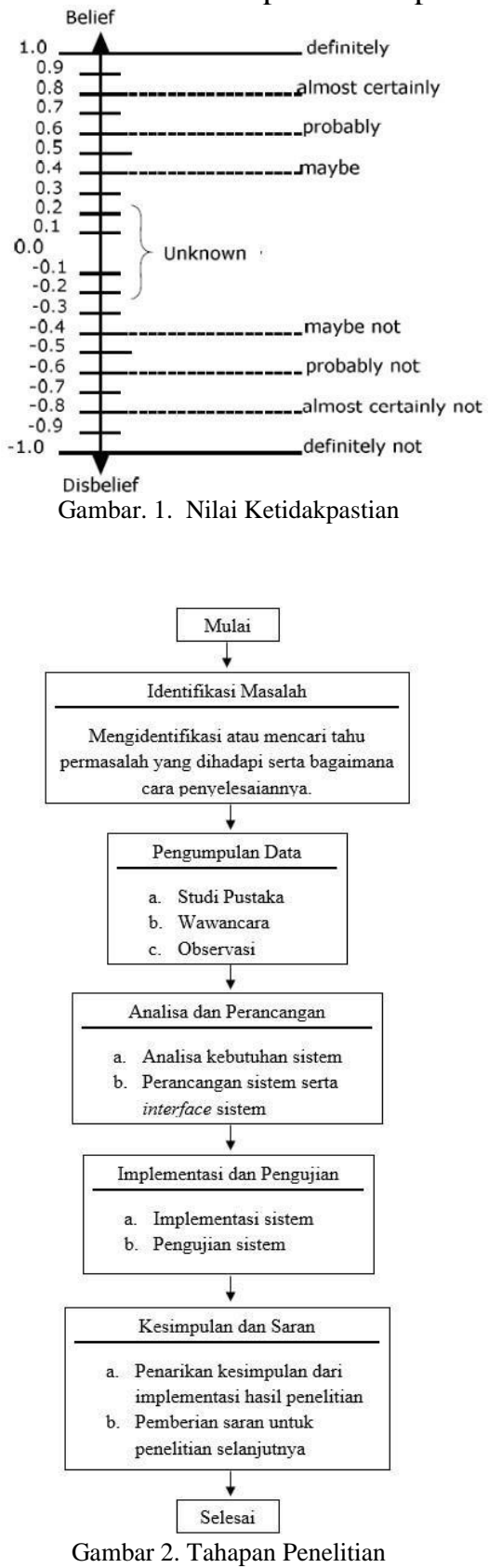

Pada Gambar 2 terdapat beberapa langkah-langkah dalam prosedur penelitian yang digunakan. Dimulai mengidentifikasi masalah dengan cara memfokuskan, mencari tahu, memahami, dan mengetahui batasan-batasan masalah yang diteliti. Kedua ialah tahap pengumpulan data yang diperlukan dalam penelitian yang mana 
pengumpulan data dilakukan dengan mengumpulkan studi pustaka, observasi serta wawancara langsung ke pihak terkait. Ketiga adalah tahapan analisa dan perancangan, pada tahap ini data-data yang sudah terkumpul akan di analisis untuk menentukan kebutuhan yang berkaitan dengan fungsi sistem yang akan dirancang serta perancangan interface awal sistem. Tahap keempat ialah implementasi dan pengujian, pada tahap ini sistem akan dirancang serta di lakukan pengujian terhadap sistem. Tahap terakhir kelima adalah kesimpulan dan saran yang mana setelah sistem telah dibuat serta dilakukan pengujian maka kesimpulan akan didapat, berapakah tingkat akurasi yang diperoleh dari implementasi sistem dengan menggunakan kombinasi metode $f c$ dan $c f$.

\section{B. Metode Pengembangan Sistem}

Pengembangan sistem pakar tidak lepas dari metode pengembangan sebuah perangkat lunak pada umumnya. Tahapan pengembangan sistem pada penelitian ini dapat dilihat pada Gambar 3.

\section{Pembangunan PerangKat Lunak}

\section{A. Basis Pengetahuan}

Berdasarkan pengetahuan yang didapat dari pakar kejiwaan serta studi pustaka, jenis gangguan jiwa skizofrenia terbagi menjadi 5 yaitu Skizofrenia Paranoid, Skizofrenia Simplek, Skizofrenia Katatonik, Skizofrenia Hebrefenik, dan Skizofrenia Residual dengan nama pengkodean D1 sampai dengan D5.

Untuk menentukan jenis gangguan jiwa skizofrenia diperlukan bebebrapa kondisi/gejala yang mana berfungsi sebagai sebuah parameter. Dari setiap jenis gangguan jiwa skizofrenia didapatkan 30 gejala yang dijadikan sebagai parameter dengan nama pengkodean G001 sampai dengan G030.

\section{B. Forward Chaining}

Pada proses forward chaining, data yang telah diinput user di proses pada mesin inferensi berdasarkan gejala yang dimasukan, kemudian gejala yang telah terkumpul tadi dilanjutkan ke proses pengelompokan untuk menyesuaikan dengan jenis penyakit pada basis pengetahuan untuk menentukan jenis gangguan jiwa skizofrenia. Adapun konsep inferensi dilakukan dengan penggunaan production rule (if...then) mekanismenya melalui forward chaining. Mekanisme inferensi dengan menggunakan metode forward chaining dapat dilihat pada Gambar 4.

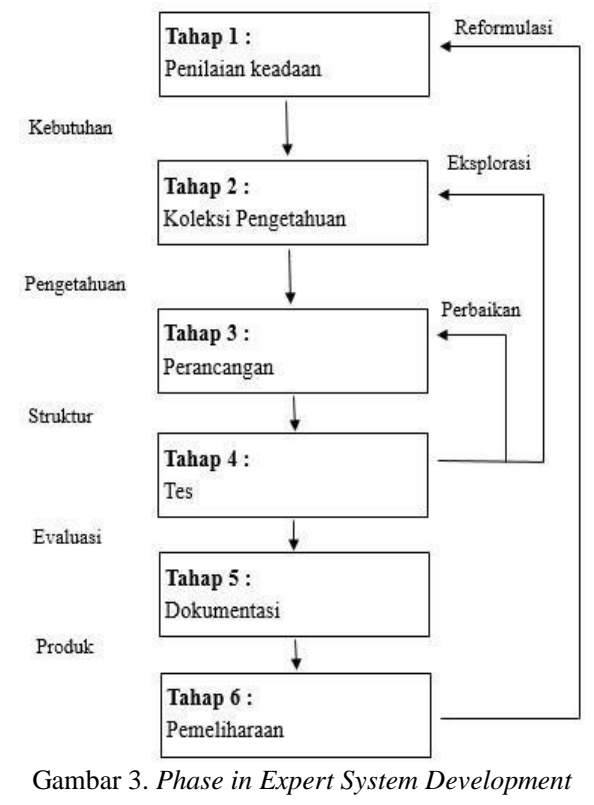




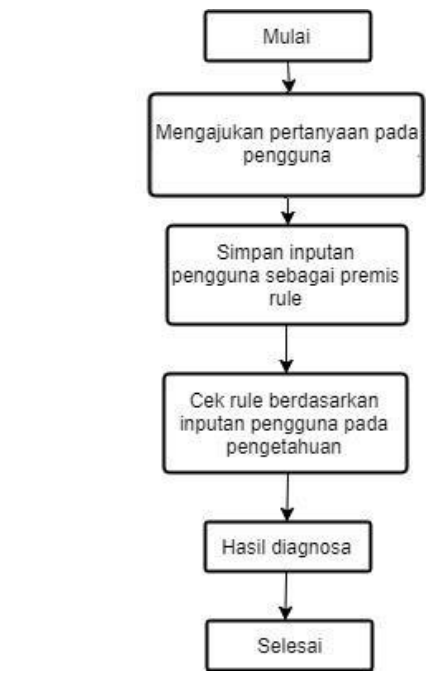

Gambar 4. Inferensi dengan Forward Chaining

\section{Certainty Factor}

Pada pengimplementasian sistem menggunakan metode certainty factor, setiap aturan memiliki nilai $c f$ yang melekat pada evidence dan rule. Pada penelitian yang dilakukan, nilai $c f$ terhadap evidence diasumsikan bernilai 1 atau disebut attenuation coefficient, sehingga hanya $c f$ yang melekat pada rule saja yang diberi nilai antara -1 sampai dengan 1.

\section{Implementasi Nilai Kepastian}

Subbab ini menjelaskan bagaimana perhitungan nilai kepastian untuk hasil diagnosa yang dihasilakn. Untuk menghasilkan nilai kepastian pada sebuah diagnosa dilakukan perhiutngan kombinasi certainty factor pada setiap gejala yang dipilih oleh user. Berikut adalah contoh perhitungan nilai kepastian yang menghasilkan diagnosa skizofrenia katatonik.

$C F(D 3, G 001, G 002)=C F_{\text {baru1 }}=0,16+0,24(1-0,16)=0,3616$

$C F\left(D 3, C F_{\text {baru1 }}, G 003\right)=C F_{\text {baru } 2}=0,3616+0,16(1-0,3616)=0,4637$, dan seterusnya

\section{E. Implementasi Sistem}

Pada tahapan implementasi antarmuka sistem adalah tahap dimana melakukan implemntasi dari hasil analisa pada bab dan subbab sebelumnya ke dalam sebuah sistem. Pada penelitian ini implementasi menggunakan bahasa pemrograman HTML, CSS, PHP, serta MYSQL.

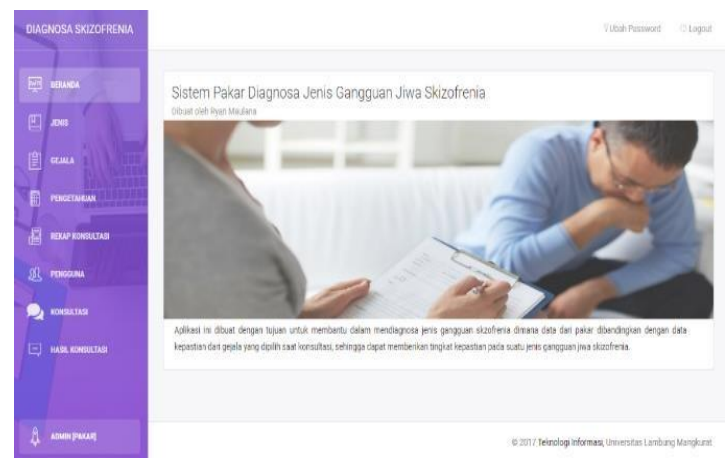

Gambar 5. Implementasi Halaman Beranda Admin 
JTIULM - Volume 02, Nomor 2, Desember 2017: 21 - 28

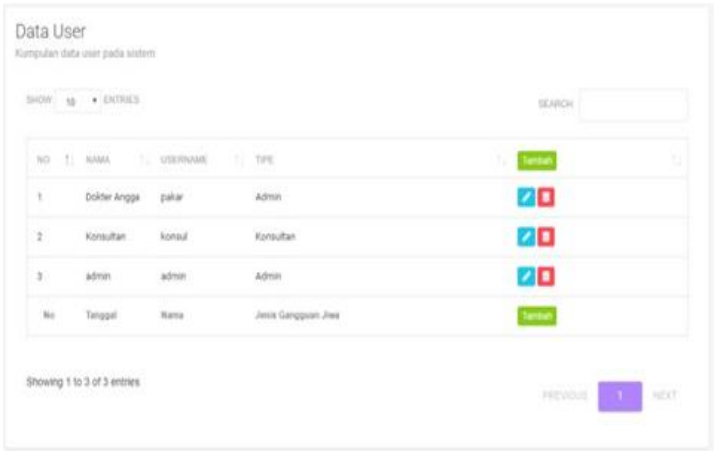

Gambar 6. Implementasi Halaman Kelola User

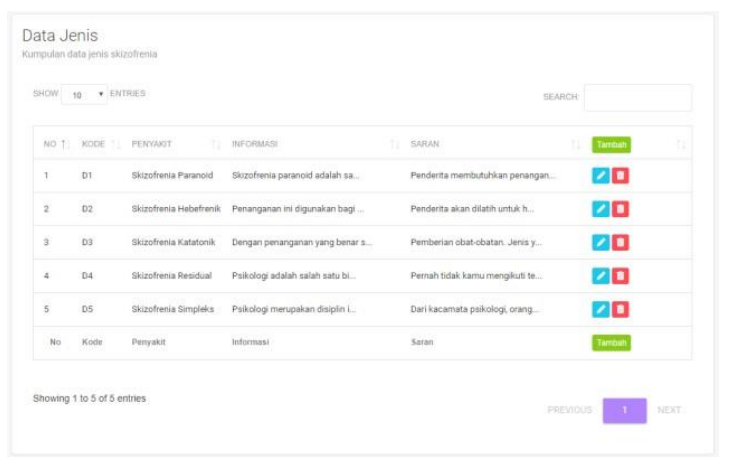

Gambar 7. Implementasi Halaman Kelola Jenis Skizofernia

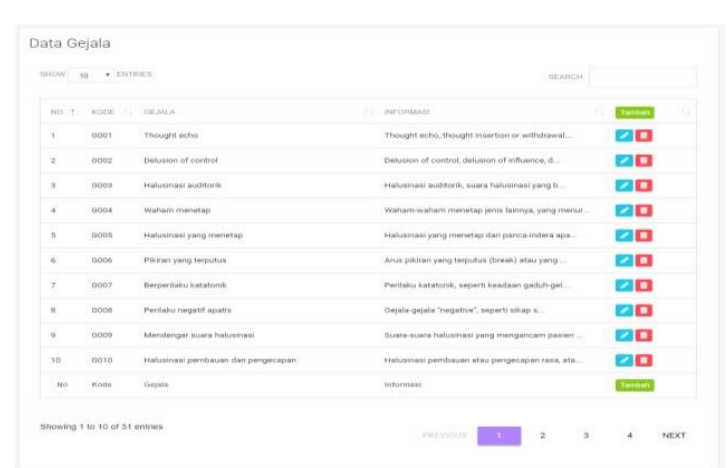

Gambar 8. Implementasi Halaman Kelola Gejala

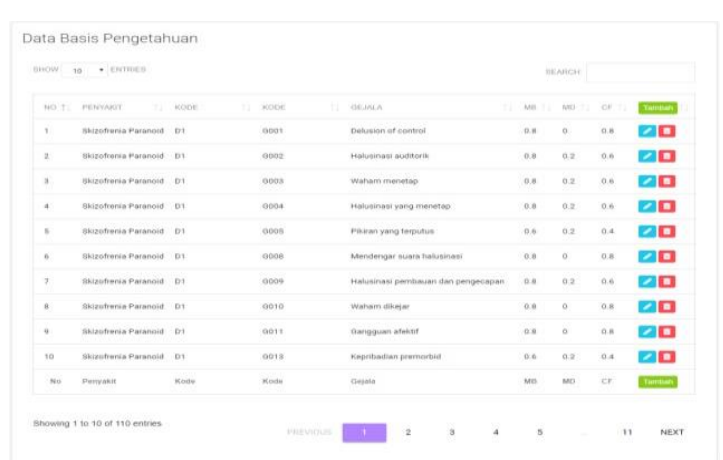

Gambar 9. Implementasi Halaman Kelola Nilai Certainty Factor

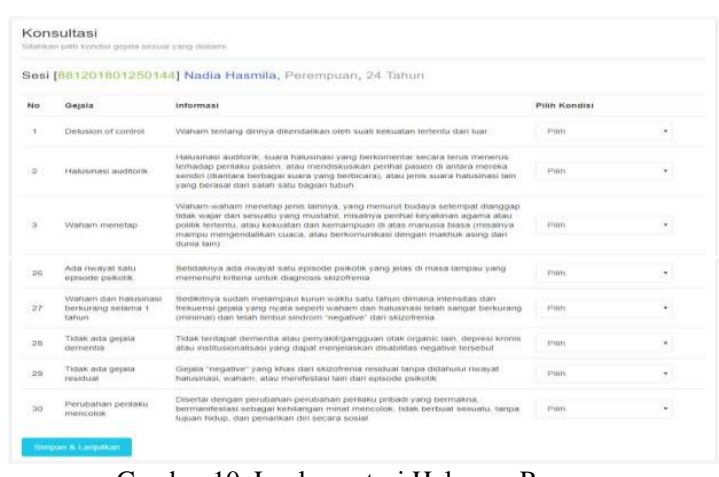

Gambar 10. Implementasi Halaman Proses 


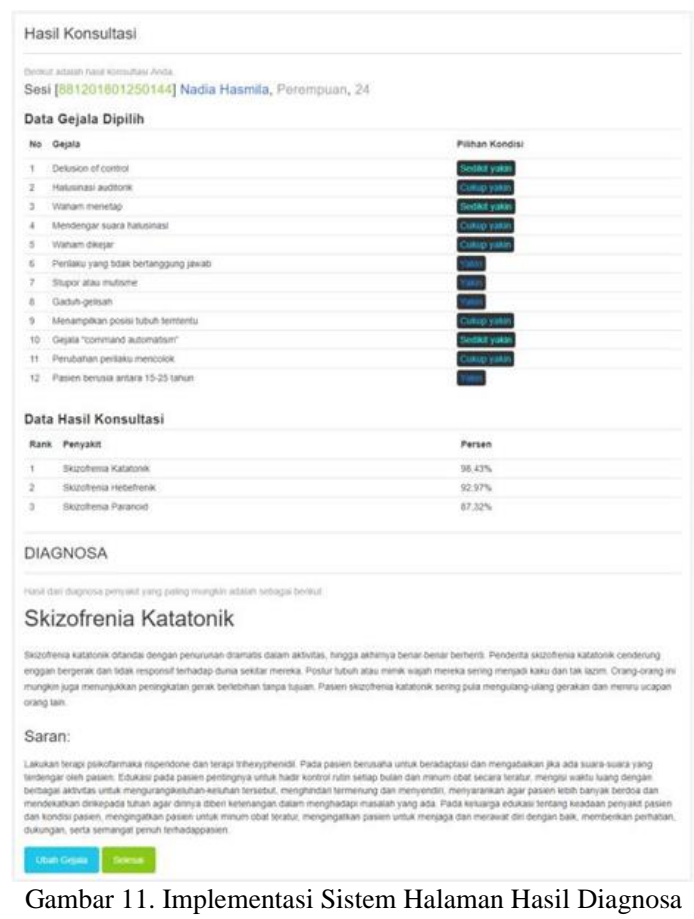

V. PENGUJian

\section{A. Hasil Pengujian}

Pada bagian ini dilakukan uji coba keakuratan pada sistem terhadap pakar. Untuk mengetahui perhitungan keakuratan sistem dilakukan uji coba dari kasus yang didapat oleh pakar. Pada tabel 1 ditampilkan 15 kasus uji coba untuk mengukur tingkat akurasi sistem terhadap kesimpulan pakar.

\section{B. Deskripsi Pengujian}

Ujicoba akurasi yang dilakukan pada sistem yaitu membandingkan output sistem terhadap kesimpulan pakar disetiap kasus. Pada ujicoba menghasilkan 14 output kasus yang sesuai terhadap kesimpulan pakar dan 1 kasus yang tidak sesuai.

Presentase keakurasian uji coba terhadap sistem adalah 93\%. Setelah dilakukan uji coba terdapat satu kasus (kasus nomor 7) yang mana output tidak sesuai dengan kesimpulan pakar, hal ini terjadi karena dikitnya gejala yang dapat digali pada sebuah kasus, maka ketepatan output pada sistem dipengaruhi oleh beberapa faktor, yang pertama adalah faktor banyaknya ketersediaan pengetahuan gejala, semakin banyak ketersedian gejala maka semakin banyak kemungkinan user memilih gejala yang seusai dengan kondisi kasus. Faktor kedua adalah bagaiman user menggali gejala-gejala terhadap sebuah kasus atau seorang pasien, disini faktor pengetahuan user sangat berpengaruh terhadap hasil output.

Tabel 1. Hasil Pengujian

\begin{tabular}{|l|l|l|l|}
\hline Pasien & Sistem & Pakar & Ket \\
\hline Pasien 1 & Paranoid & Paranoid & Sesuai \\
\hline Pasien 2 & Paranoid & Paranoid & Sesuai \\
\hline Pasien 3 & Paranoid & Paranoid & Sesuai \\
\hline Pasien 4 & Paranoid & Paranoid & Sesuai \\
\hline Pasien 5 & Hebefrenik & Hebefrenik & Sesuai \\
\hline Pasien 6 & Paranoid & Paranoid & Sesuai \\
\hline Pasien 7 & Hebefrenik & Paranoid & Tidak Sesuai \\
\hline Pasien 8 & Hebefrenik & Hebefrenik & Sesuai \\
\hline Pasien 9 & Hebefrenik & Hebefrenik & Sesuai \\
\hline Pasien 10 & Katatonik & Katatonik & Sesuai \\
\hline Pasien 11 & Residual & Residual & Sesuai \\
\hline Pasien 12 & Katatonik & Katatonik & Sesuai \\
\hline Pasien 13 & Residual & Residual & Sesuai \\
\hline Pasien 14 & Simpleks & Simpleks & Sesuai \\
\hline Pasien 15 & Katatonik & Katatonik & Sesuai \\
\hline
\end{tabular}




\section{KESIMPULAN}

\section{A. Simpulan}

Dari penelitian yang telah dilakukan dengan melihat dan mengamati sistem maka didapatkan kesimpulan sebagai berikut:

1. Kombinasi metode forward chaining dan certainty factor dapat memberikan hasil diagnosa jenis gangguan jiwa skizofrenia berdasarkan basis pengetahuan yang ada.

2. Berdasarkan hasil pengujian, tingkat akurasi sistem memiliki persentase akhir sebesar $93 \%$.

3. Sistem dapat membantu user atau dokter kejiwaan dalam mengambil keputusan dalam mendiagnosa jenis gangguan jiwa skizofrenia.

\section{B. Rekomendasi}

Adapun yang menjadi saran dari penulis untuk penelitian selanjutnya antara lain:

1. Memperluas basis pengetahuan jenis gangguan jiwa skizofrenia serta gejalanya.

2. Dapat dikembangkan dengan metode lainnya untuk mencari nilai akurasi yang lebih tajam.

\section{DAFTAR PUSTAKA}

[1] Badan Penelitian dan Pengembangan Kesehatan, "Riset Kesehatan Dasar," Kementrian Kesehatan RI, Jakarta, 2013.

[2] Norsyehan, Dhian Ririn Lestari, and Yeni Mulyani, "Terapi Melukis Terhadap Kognitif Pasien Skizofrenia Di Rumah Sakit Jiwa Sambang Lihum," Dunia Keperawatan, vol. 3, no. 2, pp. 71-78, 2015.

[3] Jeffrey S. Nevid, Spencer A. Rathus, and Beverly Greene, Psikologi Abnormal, 5th ed., vol. 1. Erlangga, 2005.

[4] Erianto Ongko, "Perancangan Sistem Pakar Diagnosa Penyakit pada Mata," J. Time, vol. II, no. 2, 2013.

[5] F. I. Mevung, A. Suyatno, and S. Maharani, "Diagnosis Penyakit Kejiwaan dengan Menggunakan Metode Certainty Factor," Pros. SAKTI Semin. Ilmu Komput. Dan Teknol. Inf., vol. 2, no. 1, pp. 374-380, Mar. 2017.

[6] Richard P. Halgin and Susan Krauss Whitbourne, Psikologi Abnormal: Perspektif Klinis pada Gangguan Psikologis, 6th ed., vol. 1. Jakarta: Salemba Humanika, 2010

[7] Sri Kusumadewi, Artificial intelligence (teknik dan aplikasinya), 1st ed. Yogyakarta: Graha Ilmu, 2003.

[8] J. C. Giarratano and G. D. Riley, Expert Systems: Principles and Programming, Fourth Edition, 4 edition. Boston, Mass.: Course Technology, 2004.

[9] T. Sutojo, E. Mulyanto, and V. Suhartono, Kecerdasan buatan. Andi Offset, 2011. 